\title{
Could Payments for Environmental Services Improve Rangeland Management in Central Asia, West Asia and North Africa?
}

Celine Dutilly-Diane, Centre de Coopération Internationale en Recherche Agronomique pour le Développement (CIRAD)

Nancy McCarthy, International Food Policy Research Institute, Francis Turkelboom, International Center for Agricultural Research in Dry Areas (ICARDA),

Adriana Bruggeman, International Center for Agricultural Research in Dry Areas (ICARDA),

James Tiedemann, International Center for Agricultural Research in Dry Areas (ICARDA),

Kenneth Street, International Center for Agricultural Research in Dry Areas (ICARDA),

and Gianluca Serra, Conservation Biologist

\begin{abstract}
The CGIAR Systemwide Program on Collective Action and Property Rights (CAPRi) is an initiative of the 15 centers that belong to the Consultative Group on International Agricultural Research. The initiative promotes comparative research on the role played by property rights and collective action institutions in shaping the efficiency, sustainability, and equity of natural resource systems. CAPRi's Secretariat is hosted by the International Food Policy Research Institute's (IFPRI) Environment and Production Technology Division (www.ifpri.org).

CAPRi Working Papers contain preliminary material and research results and are circulated prior to a full peer review in order to stimulate discussion and critical comment. It is expected that most Working Papers will eventually be published in some other form, and that their content may also be revised.

Copyright ( $)$ January 30, 2007 International Food Policy Research Institute. All rights reserved. Sections of this material may be reproduced for personal and not-for-profit use without the express written permission of but with acknowledgment to IFPRI. To reproduce the material contained herein for profit or commercial use requires express written permission. To obtain permission to reprint, contact the IFPRI Communications Division at ifpri-copyright@cgiar.org.
\end{abstract}

CGIAR Systemwide Program on Collective Action and Property Rights (CAPRi) c/o INTERNATIONAL FOOD POLICY RESEARCH INSTITUTE 


\begin{abstract}
Although several institutional and management approaches that address the degradation of the rangelands have been tested in the dry areas of Central and West Asia and North Africa (CWANA), impact has been limited. Nonetheless, the development of National Action Plans to combat desertification highlights the interest of governments to tackle this issue. Payment for Environmental Services (PES) may be a viable policy option, though, to date, most PES programs have focused on the management of different resources (forests, watersheds). The purpose of this paper is to examine whether PES could be a viable option to promote sustainable rangelands management in the dry rangelands of CWANA. Specifically, it focuses on the scientific gaps and knowledge related to the local and global environmental services produced by rangelands and addresses questions related to the beneficiaries of these services. Institutional conditions necessary for the implementation of such schemes are discussed.
\end{abstract}

Keywords: environmental services, rangelands, North Africa, West Asia, Central Asia. 


\section{TABLE OF CONTENTS}

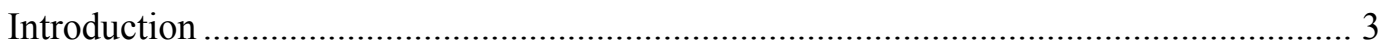

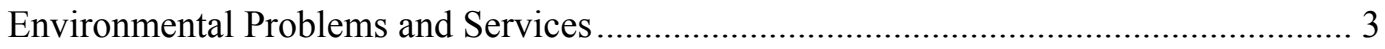

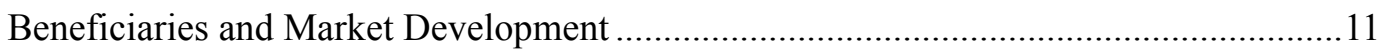

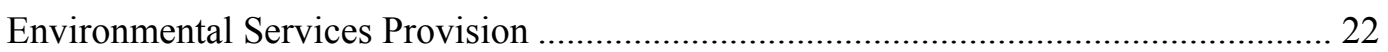

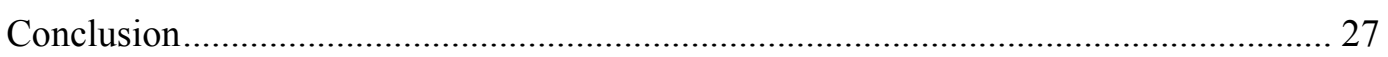

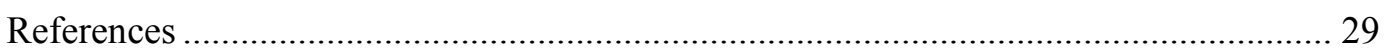




\section{Could Payments for Environmental Services Improve Rangeland Management in Central Asia, West Asia and North Africa?}

Celine Dutilly-Diane, ${ }^{1 *}$ Nancy McCarthy, ${ }^{2}$ Francis Turkelboom, ${ }^{3}$ Adriana Bruggeman, ${ }^{4}$ James Tiedemann, ${ }^{5}$ Kenneth Street, ${ }^{6}$ and Gianluca Serra ${ }^{7}$

\section{INTRODUCTION}

As the awareness of policymakers, private sector, and civilians for environmental sustainability is increasing and the environmental services provided by various ecosystems of the planet are better recognized, new economic instruments are being developed to internalize these services into market transaction. Payments for environmental services (PES) schemes is one of them, operating under the principle that resource users in position to provide environmental services - through alternative land management and land use practices - should be compensated for the costs of their provision.

To date, most payment schemes for environmental services have been developed for forests protection (Landell-Mills and Porras 2002), biodiversity conservation (Pagiola et al. 2004), or watershed management (Kosoy et al. 2006), but they are not a common approach for rangeland management. Apart from a project ${ }^{18}$ that focuses on silvopastoral systems to

\footnotetext{
${ }^{1}$ Centre de Coopération Internationale en Recherche Agronomique pour le Développement (CIRAD), UPR Livestock systems and International Center for Agricultural Research in Dry Areas (ICARDA) - PO Box 5466, Aleppo, Syria. Fax:+963 212213490 Email: c.dutilly-diane@cgiar.org *Corresponding author ${ }^{2}$ International Food Policy Research Institute (IFPRI) - Environment and Production technology Department 2033 K Street NW, Washington DC 20006-1002, USA. Fax: +1 2024674439 Email: n.mccarthy@cgiar.org

${ }^{3}$ International Center for Agricultural Research in Dry Areas (ICARDA) - PO Box 5466, Aleppo, Syria. Fax: +963212213490 Email: f.turkelboom@cgiar.org

${ }^{4}$ International Center for Agricultural Research in Dry Areas (ICARDA) - PO Box 5466, Aleppo, Syria. Fax:

+963212213490 Email: a.bruggeman@cgiar.org

${ }^{5}$ Email: jim.tiedeman@yahoo.com

${ }^{6}$ International Center for Agricultural Research in Dry Areas (ICARDA) - PO Box 5466, Aleppo, Syria. Fax: +963212213490 Email: k.street@cgiar.org

${ }^{7}$ Independent Conservation Biologist, www.gianlucaserra.com, Email: puffo_blue@hotmail.com

${ }^{8}$ Regional (Colombia, Costa Rica, Nicaragua) Integrated Silvopastoral Approaches to Ecosystem Management, funded by GEF.
} 
improve degraded pasture land in Latin America, the only case known to the authors is the Natural Resources Conservation Services (NRCS) Grassland Reserve Program in the USA, created in 2002 . This voluntary program pays ranchers to restore or protect private rangelands. Other projects in the dry rangelands concern the valuation of environmental services. In south Texas, Lemberg et al. (2002) combined an ecological, hydrological, and economic model to assess the effects of brush control on improved downstream water supply in a large rangeland watershed. In Peru, Quezada (2003) conducted a complete economic valuation of the biodiversity and environmental services of the High Andean grasslands. In Central Asia, the carbon studies component of the Livestock Management and Rangeland Conservation Tools project is providing data on rangeland carbon flux (Wylie et al. 2004).

Fisher et al. (1994) presented evidence that shows that grassland soils can store as much as $70 \mathrm{t} / \mathrm{ha}$ of carbon, which is similar to forest soils and much more than previously thought. Farage et al. (2003) caution that semi-arid lands are particularly susceptible to soil degradation and carbon loss, and that management is extremely important in these regions. In addition, appropriate management of the rangelands could reduce wind erosion and frequency of dust-storms, limit the erosion of flora and fauna biodiversity, and improve water productivity.

While the first assessments of PES programs are being released (Sierra and Russman 2006; Alix-Garcia et al. 2005; Mayrand and Paquin 2004), this paper conducts a review of environmental services provided to rangelands in dry areas of Central Asia, West Asia, and North Africa (CWANA) in order to better understand whether Payment for Environmental Services could provide an incentive for sustainable management. Unlike many other PES schemes that are based on individuals undertaking investments or changing management techniques using their own asset base, most of the rangelands in the semi-arid and arid areas 
of the CWANA region are common-pool resources, meaning that local institutional development as well as the national political and legal framework will be instrumental in evaluating both the costs and benefits of rangeland PES schemes in the region. Determining just who bears those costs and receives the benefits can be quite a difficult task. Thus, given the common-pool nature of the resource, any evaluation must take into account the incentives and capacity to manage the resource base as well as to provide the investments needed to generate public goods in these areas.

\section{ENVIRONMENTAL PROBLEMS AND SERVICES}

Rangelands in the drylands of the CWANA region ${ }^{9}$ can be defined as non-arable land, i.e. those areas not suitable for crop production due to low (less than 200mm) and highly variable rainfall, shallow soils, a high percentage of rocks, steep slopes, or a combination of these characteristics. The indigenous vegetation is mostly grass or grass-like plants, and shrubs not dominated by trees (Forage and Grazing Terminology Committee 1992). These rangelands contribute to the livelihoods of some of the poorest and most vulnerable communities in the world primarily by providing grazing for livestock.

Rangelands are estimated to cover 555 Mha of West Asia and North Africa, constituting 90 percent of the estimated degraded drylands (Lal 2002), with an additional 240 Mha in Central Asia and the Caucasus. In Algeria, studies of the steppe show a regression of plant cover of over 50 percent and the productivity of alfa steppes has been reduced by 4 for degraded grazing and by 50 percent for palatable grazing since the 1970's (Aidoud and

\footnotetext{
${ }^{9}$ Rangelands in CWANA can include non-arable areas in high rainfall (e.g. mountain) areas. In this paper, we focus on dry rangeland areas, i.e. the steppe.
} 
Nedjraoui 1992 ). In Morocco, Boulanouar et al. (2000) estimated that 80 percent of the rangelands are moderately degraded, while about 12.5 percent are severely degraded.

Beside these figures from North Africa, information on rangeland degradation is scattered and incomplete, representing a formidable constraint to the development of environmental services markets in the region. Therefore, a first important task is to develop land degradation monitoring and prediction tools, which, together with the development of mitigation options, are three key elements in the current national action plan to combat desertification (UNCCD 2001). However, there are many challenges:

- Many dryland ecosystems are inherently non-equilibrial, meaning that changes do not progress in a gradual and orderly manner from pioneer to climax vegetation assemblages, and evidence of global climate change makes the task of assessment more difficult.

- Monitoring desertification requires aggregating a number of indicators, but there is still disagreement about which set of indicators to use (Squires 2001).

- Even where rangeland specialists agree that a rangeland can be characterized as degraded, specialists, as well as herders themselves, can disagree on the causal factors. Given such uncertainty, identifying concrete management options that both service providers and purchasers agree would lead to greater services is likely to be very difficult.

Nevertheless, in general, scientists agree that rangelands are degrading and that improved management is extremely important in this region. Four main public services could be provided by well-managed rangelands. They include: 1) carbon sequestration, 2) conservation of biodiversity in situ and in adjacent agro-ecological zones, 3) wind-erosion reduction, and, finally, 4) improved water productivity and flood erosion control. Below, we review the potential for rangelands in CWANA to generate these services. 


\section{Carbon sequestration}

According to the 1995 IPCC estimates, rangelands may play an important role in sequestering atmospheric carbon (Allen-Diaz et al. 1996), especially through the large size of these rangelands. World grasslands store anywhere between 200 to $420 \mathrm{Pg} \mathrm{C} \mathrm{yr}^{-1}$ in the total ecosystem, a large part of this being below the surface (Robert 2001). If the carbon sequestration on optimally grazed lands is greater than on unmanaged lands (un-grazed or over-grazed lands), the effects are inconsistent given the diversity of ecological conditions (Smith et al. 2006).

Data on carbon sequestration potential of rangelands are rare in the CWANA region. Lal (2002a) estimated that the soils of WANA have a potential annual C sequestration rate of 200-400 Tg C yr, ${ }^{-1}$ accounting for 20 percent of the potential of global dryland ecosystems. Among several technical strategies proposed by the author, desertification control offers a

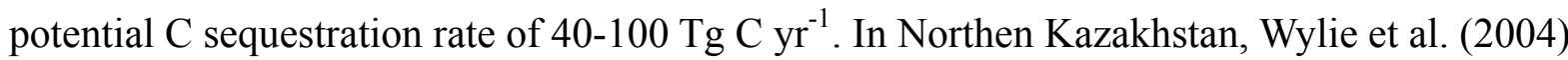
estimated that rangelands in this ecoregion had an average of $1.27 \mathrm{Mg} \mathrm{C} /$ ha sequestration of $\mathrm{CO} 2$ during the 2000 growing season. More data are being analyzed to close the annual carbon budget for the Kazakh steppe.

\section{Enhanced biodiversity}

Biodiversity provides an agro-ecosystem with the ability to adapt to changes in the environment. A healthy rangeland maintains a high biodiversity not only of the plant species but also of the whole food chain.

\section{Plant biodiversity}

Three factors are considered to be the major causes of lost plant biodiversity on rangelands: overgrazing, collection of woody species for fuel, and conversion to cropland. 
With overgrazing, the more palatable plant species disappear, and the less palatable or unpalatable species remain filling in the gaps and empty niches (West 1993). Uprooting or cutting of woody species for fuel destroys the microenvironment in which other species flourish. Invader plants dominate overgrazed rangelands and fill in the voids left by the suppressed palatable plants, replacing the diverse biotic-rich native plant communities. Resulting monocultures create their own self-sustaining environment.

As farming becomes more mechanized and population pressure increases, rangeland is ploughed and converted to crop land, destroying the protecting vegetative cover. In these harsh environments, the soil becomes prone to erosion, and within a few years the land is abandoned, reverting back to rangeland. However, once destroyed by cultivation, native species are slow to return, and the vegetation often consists of only a few native weedy annuals. It is nearly impossible to replace the once rich biodiversity by re-seeding or restoration with currently available technology; the rich native biodiversity is permanently lost once rangeland is cultivated. Syria is the only country in the region that attempted to address this issue in 1995 by banning the cultivation of lands below the $200 \mathrm{~mm}$ precipitation isohyet (a line drawn on a map connecting points having equal rainfall at a certain time or for a stated period). Yet, most of the land remains devoid of protective native vegetation.

The cost of rangeland degradation and desertification can also be measured in terms of the loss of valuable biodiversity in adjacent agro-ecological zones. This impact is particularly worrying in the Central Asia and Caucasus region, the location of two Centers of Plant Diversity. Although many crops do not originate in the rangelands per se, their diversity is affected by the status and use of the rangelands within the context of the broader agroecosystems within the region. Over-grazing and mismanagement leads to a decline in plant biomass production and, thus, in the ability of rangelands to provide feed for animal 
production. As this occurs, demands for cultivated supplementary feed on adjacent agroecological zones, which contain valuable agro-biodiversity, are increased. This leads to genetic erosion as the grazing pressure increases in these areas. Evidence of genetic erosion in a heavily grazed range transition zone was observed in 2001 in southeast Azerbaijan by an ICARDA-led plant collection mission (N.I. Dzyubenko, pers. comm.). The frequency of pasture and medic species within eight genera had decreased from 72 in the 1920s to 35 in 2001 (Table 1).

Table 1--Genetic erosion of pasture species in southeast Azerbaijan

\begin{tabular}{lcc}
\hline Genra & $\begin{array}{c}\text { Species observed in } \\
\text { the early } 20^{\text {th }} \text { century }\end{array}$ & $\begin{array}{c}\text { Species observed } \\
\text { in 2001 }\end{array}$ \\
\hline Trifolium & 12 & 8 \\
Onobrychis & 12 & 3 \\
Medicago & 18 & 12 \\
Hedysarum & 8 & 2 \\
Lotus & 8 & 4 \\
Melilotus & 8 & 3 \\
Coronilla & 4 & 2 \\
Galega & 2 & 1 \\
\hline Total & 72 & 35 \\
\hline
\end{tabular}

\section{Animal biodiversity}

The degradation of the vegetation cover also affects the whole food chain of the ecosystem, from the herbivore insects to the insectivorous birds and the large-sized mammal species (gazelle, caprines). Destruction and degradation of habitats through human activities is the single most serious threat to fauna world-wide and is the cause of 85 percent of globally threatened bird species (BirdLife International 2004). The Northern Bald Ibis (Geronticus eremita), a bird considered to have disappeared from Syria more than 70 years ago and recently re-discovered in the country (Serra et al. 2003), could be considered an excellent ecological indicator for the rangelands of Syrian (Al Badia). This bird species is listed as 
globally critically endangered (IUCN 2003); only five adults presently survive in Syria - the last survivors of the whole eastern population once occurring in Southern Europe and the Middle East. The Northern Bald Ibis is an insectivorous colonial bird and was very common within the whole Al Badia until only 15-20 years ago. Although habitat degradation is not the only direct cause for the almost extinction of this species from al Badia (heavy human disturbance and uncontrolled hunting being among the key others), the time frame of its inexorable decline coincides with the beginning of the heavy degradation of vegetation cover of al Badia (Serra et al. 2003).

The erosion of flora and fauna diversity can be stopped and even the biodiversity can be improved through rangeland rehabilitation. The rangelands of al Talila reserve, $30 \mathrm{~km}$ south-east of Palmyra in Syria, offers an interesting example. After the land had been protected from sheep grazing for about a decade, the difference in vegetation cover and in occurrence and density of fauna species inside versus outside the reserve is stunning. For instance, during a three-year bird survey, five species were found only inside the reserve, while four others were detected at significantly higher rates inside the reserve versus outside of it (Serra et al. 2005). For ground-dweller animals the comparison is more significant: several mammal and reptile species are found only inside al Talila (G. Serra, pers comm.).

\section{Wind erosion reduction}

According to the Global Assessment of Human Induced Soil Degradation (GLASOD), most of the wind erosion occurs in Africa and Asia, affecting an estimated 310 Mha. Wind erosion is the result of climatic variations and human activities such as the cultivation of marginal dry areas, fuel and fodder collection, overgrazing and trampling by animals, and offroad vehicle use (Middleton and Thomas 1997). Wind-blown dust can be transported over 
short to very long distances and affects local communities as well as distant countries and

continents in several ways:

- Soil nutrients transfers: Wind erosion can remove the fertile topsoil and reduce soil depth, which can result in a shift to less desirable plants. On the other hand, deposits of wind-blown soil can contribute to soil fertility and furnish essential nutrients. Usually wind-blown sediments are more fertile than the surface of the parent soil (Reynolds et al. 2001).

- Damage to agricultural production systems: Heavier sediments, which move by saltation, can damage crops, and excessive deposits can bury plants. A coating of dust has been found to increase leaf temperatures and water loss, while decreasing intake of carbon dioxide by plants. In China, for example, millions of dollars are annually lost from the reduction of grain production, decline of quality of vegetables and fruit, and drop in number of silkworm cocoons (Northcut 2001), while in North Africa several oases are buried (Sivakumar et al. 1998).

- Ecological impact: By one estimate, anywhere from about 990 to 1,650 tons of soil dust enter the world's atmosphere each year. In fact, dust in the air has been identified as one possible suspect in atmospheric instability and climate change (Northcut 2001). Bacteria and fungi, which are transported in plumes of dust from the Sahara across the Atlantic, are suspected to cause sea fan disease in the Caribbean coral reefs (Shinn et al. 2000). On the other hand, in-cloud photochemical reduction of desert dust can be an important source of bio-available iron, which can result in phytoplankton blooms in oceans (Saydam and Senyuva 2002).

- Health: Dust storms increase the risk of human health-related problems. In Australia, it is estimated that 20 percent of asthma problems are linked with wind-borne dust (CSIRO 2000). Animal health can also be affected by dust.

- Habitation, infrastructure and industry: Poor visibility causes road accidents, diversion of flights, and closing of businesses and schools, while wind sedimentation can bury roads, fences, railways and other structures. Airborne dust can work its way inside mechanical and electrical components, adding to the costs of maintaining equipments. Another economic impact is the moving of North African real estate to Bermuda (Northcut 2001).

Research has shown that the frequency and severity of dust storms can be reduced to almost negligible proportions through proper management practices. However, to achieve sustainable impact, there is a need for a combination of political, social, biological, economic, educational and engineering approaches (UNCCD 2001). 


\section{Improved water productivity}

The natural range vegetation in the dry environments of WANA, both annual and perennial, is well adapted to survive long periods of drought and to capture the limited but sometimes intensive rainfall.

Degradation of the vegetative cover of the rangelands, leaves a large percentage of the soil bare. The unprotected soils are affected by sealing and crusting, properties that are found in many soils in the dry areas (Levy et al. 1986). Rain falling during small and low intensity events will evaporate from the hard, bare soil surface or puddles without any productive use, whereas high-intensity and long-duration events will cause surface runoff and flash floods. These surface flows collect in wadis, inland salt sinks or surface depressions, from which the water evaporates back to the atmosphere or infiltrates to recharge the groundwater such as the Nubian Sandstone aquifer below the deserts of Egypt, Libya, Sudan, and Chad (FAO et al. 2003).

The surface runoff also detaches and transports soil particles and valuable nutrients from surface soils, with the fine particles (silt and clay) being carried along with the water to finally settle in depressions. These silts and clay will seal the surface of these ponds, thus, reducing groundwater recharge and increasing the loss of local water resources to evaporation.

The main effects of micro-catchment water-harvesting systems and vegetation restoration would be the reduction of flooding and erosion, and improved local rainfall water productivity. Groundwater recharge is likely to be a minor component. To truly improve groundwater recharge, macro-catchment water-harvesting techniques such as check dams, infiltration basins, and recharge wells are needed (Bouwer 2002). Whatever interventions are 
made to improve the local water use, any potential effects on downstream water users need to be considered.

\section{BENEFICIARIES AND MARKET DEVELOPMENT}

Better rangeland management will have impacts at a range of levels, from a global impact by generating environmental services, which we have seen could be quite substantial, to a local impact. We first consider the beneficiaries, then examine issues of market development as evaluating the services produced and identify the likely purchasers of environmental services. We finally focus on the impacts PES development could have on the providers and the rangeland population.

\section{Multi-scale beneficiaries}

Some environmental services will benefit the global population (global good), whereas others will benefit specific groups at regional and local scales (Table 2). 
Table 2. Principal benefits and beneficiaries of sustainable rangeland management at various spatial scale.

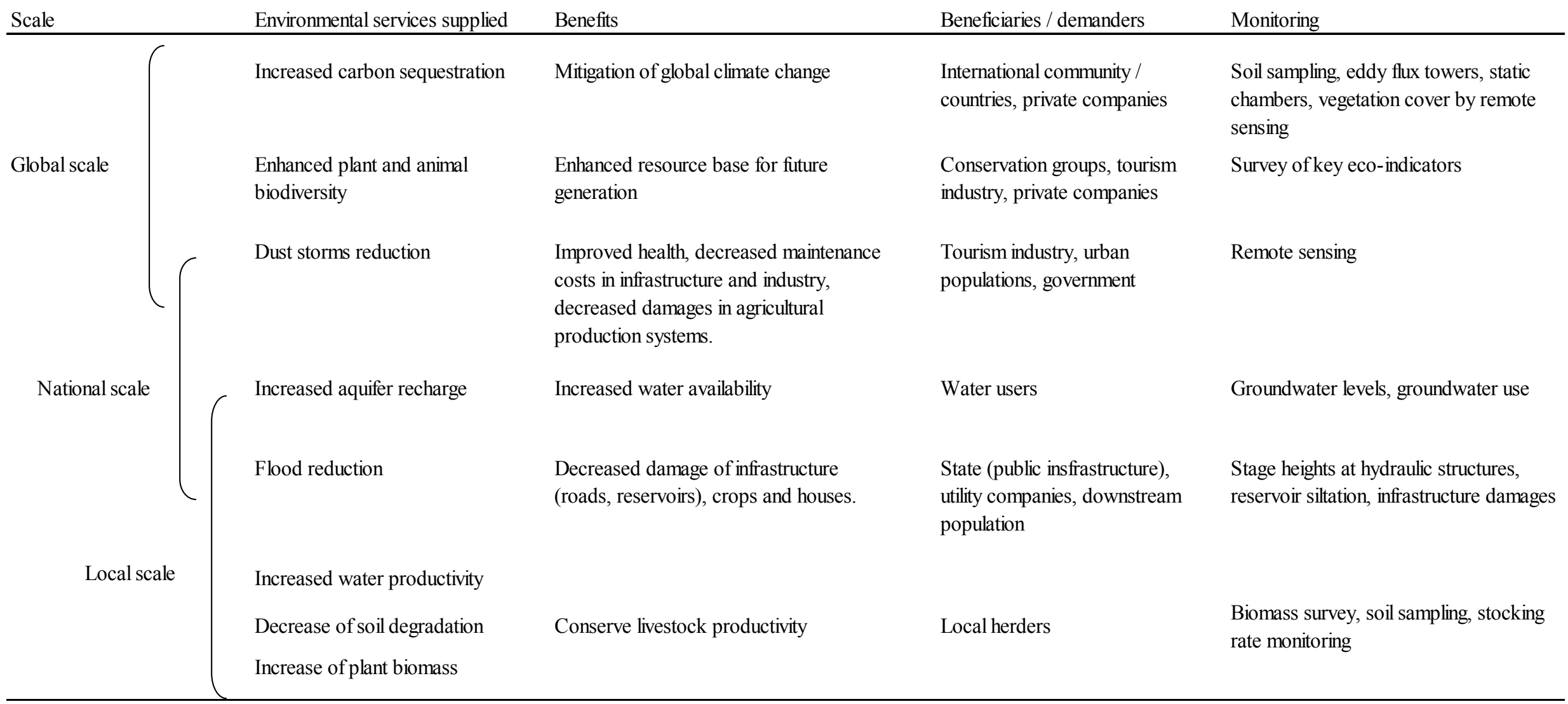


The primary beneficiary of carbon sequestration and biodiversity conservation would clearly be the "world" population (including future generations).

Other environmental services such as reduction of wind erosion and sedimentation are beneficial at both the local and regional scales. Reducing wind erosion will benefit the population living in and from rangelands; in addition, small population numbers and less infrastructure susceptible to damage implies that the off-site impacts, particularly dust, may far exceed the on-site impacts (Piper 1989).

Water related services are probably those that offer more balance between on-site and off-site benefits, though it still depends on the individual case in question. Improved vegetative rangeland cover will increase in situ rainfall water-use efficiency by turning the rain into biomass, while the reduction of floods will decrease infrastructure and cropland damage downstream. Groundwater recharge interventions could provide water for local communities, or the water could be pumped and piped to more remote villages and towns.

\section{Environmental valuation}

Once the beneficiaries are identified, ecosystem services will have to be valuated to facilitate the development of markets. However, because of the inherent spatial and temporal variability of the natural processes involved, and the interdependent and the intangible nature of such services, putting a value on them is difficult (Turner et al. 2003). Today, two conflicting methods are mainly used (Farber et al. 2002): i) the ecological valuation methods that take into account the internal structure of ecosystems and derive value by a cost-ofproduction approach, but neglect the consumer preferences, and ii) the economic valuation methods, which are based on consumer preferences and combine a set of cost-benefit, hedonic 
pricing, and contingent valuation methods (Costanza et al. 1997; Bienabe and Hearne 2005) to approach the different environmental values. These systems neglect the ecological interdependencies.

Furthermore, both evaluation systems do not capture the normative and ethical aspects of the ecosystem valuation. In addition, merging the three aspects of nature, economy, and society is the current challenge of valuing ecosystem services (Winkler 2006).

\section{Market development}

Carbon sequestration and biodiversity conservation are global public goods; their consumption cannot be attributed to well-identified beneficiaries. Nonetheless, growing public awareness of the benefits of these goods has meant that governments, international NGOs, and private companies are now paying for these services. All the CWANA states, except Iraq, have ratified the Convention to Combat Desertification (UNCCD), the convention on Biological Diversity (UNCBD), and the Convention on Climate Change (UNFCCC), which are necessary for governments in order to access international support for providing such services. The Kyoto protocol has first been ratified by the Central Asia and Caucasus, and lately by the WANA countries ( 7 countries of the region have not ratified it). The current Kyoto Protocol favors the emerging economies of the Central Asia region, while the WANA rangelands are not eligible under the Clean Development Mechanism. ${ }^{10}$

\footnotetext{
${ }^{10}$ Markets for carbon sequestration have emerged since the Kyoto protocol signing in 1997. Rangelands in CWANA qualify under 'Grazing Land Management - Re-vegetation of semi-arid and arid lands with shrubs or grasses', which is not eligible under the Kyoto Clean Development Mechanism (CDM). The CDM for Land Use, Land Use Change, and Forestry (LULUCF) is limited to afforestation and reforestation activities in the first commitment period (2008-2012). However, some Central Asian countries are eligible, as "economies in transition" under Joint Implementation (JI). For the WANA countries, the second window of the BioCarbon Fund will explore options for Emission Reductions through the CDM through activities other than afforestation and reforestation. They are, therefore, not eligible for Kyoto credits in the first commitment period, but may be creditable under emerging carbon management programs.
} 
Parallel to the Kyoto Protocol's CDM, a voluntary market for carbon offsets is emerging, where public or private organizations exchange carbon credits for reasons other than regulatory compliance (Taiyab 2005). Although this market is small, based on highly variable prices (from USD 5 to USD 35 per tCO2), and lacking transparency and standards, it is growing rapidly and could represent a good alternative for the WANA countries.

Unlike carbon sequestration and biodiversity conservation, there are tangible, negative externalities associated with wind and water erosion, where "upstream" users affect

"downstream" benefits, which creates a likelihood of downstream beneficiaries having greater incentives to pay for services to reduce wind and water erosion. Additionally, downstream benefits can be both "private" (improved health, less costly expenditures on privately-owned mechanical equipment and crops, more valuable tourism industry) and public (less costly maintenance of infrastructure), meaning again that identifying "demanders" may be easier than the case with either carbon sequestration or biodiversity services.

Finally, different environmental services may not be complementary, i.e. increased investment in providing one service may have a negative impact on other environmental benefits. For example, rehabilitating rangelands through shrub plantations may increase carbon sequestration, but have negative side effects on biodiversity. However, it might also be possible to bundle environmental services (Landell-Mills et al. 2002); combining services for financing might help to avoid this problem. In addition, if single environmental benefits are relatively small on the national scale, merging them could increase the chance of funding in the global arena and increase the payment each provider will receive. Finally, merged bundles (environmental services sold together that cannot be divided among different purchasers) may induce a reduction in transaction costs. 


\section{Impact on local population}

PES programs are not poverty reduction programs, but their implementation can have a positive impact on reducing poverty when the program is well planned (Pagiola et al. 2005). Potential benefits can be directed through three main channels: i) increase in local environmental benefits themselves, such as reduced wind erosion, groundwater recharge, and flood prevention, ii) local indirect benefits on livestock productivity generated by healthier and better managed rangelands, and iii) payments made to the environmental services providers.

Generally, provision of certain ecosystem services may generate both costs and benefits. For instance, creation of reserve grazing lands or enforcing seasonal stock limits may lead to greater forage productivity and greater diversity of forage species on restricted rangelands, which in turn will lead to improved animal productivity as well as reduced vulnerability to climate events. However, herders may also suffer losses due to reduced access to various range resources while the range is regenerating, and losses from increased grazing pressure on remaining rangelands can be quite high. The net impact will be a function of the options available to reduce rangeland degradation and, in many cases, trade-offs are likely (Section 5.2). Additionally, even net benefits are likely to differ widely among communities and household members.

\section{PES Implementation: Some Institutional Issues}

Before addressing issues related to the provision of environmental services, this section considers some institutional issues that will have to be addressed in the implementation of a PES scheme. First, property rights will have to be clarified in order to identify who will be the potential providers of environmental services and therefore the 
payment receivers. Then, transactions costs resulting from matching the supply and demand side will have to be managed.

\section{Land tenure}

Rangelands in these semi-arid and arid areas are generally under some form of state and, sometimes, tribal tenure. Very little is "private" in a conventional, freehold tenure sense. As many authors have noted, the capacity to spread climatic risk by having access to a wide range of pasture resources implies that non-private tenure arrangements are likely to be preferred by livestock owners - and, importantly, others who have secondary (or "weaker") claims to various resources found on these rangelands (Goodhue and McCarthy 1999; NiamirFuller 1999). There may well be significant trade-offs in designing payment mechanisms that recognize and accommodate various rights holders.

We can draw insights, however, from several institutional approaches that have been applied in CWANA. These can be classified into three main approaches (Ngaido et al. 2002): i) state appropriation that implies the revoking of tribal control (with traditional institutions continuing to operate informally and manage range resources) (Rae 2000), ii) control by pastoral communities/organization that consists of giving pastoral communities different degrees of control over the access, use, and management of resources, and iii) formal titling of tribal collective land which provides the tribes with a legal basis for a wide range of property rights.

These different experiences have had limited impacts on halting rangeland degradation; either over-use or under-investment continue to plague these many areas. Taking land directly out of production by the state is usually very expensive since monitoring and enforcement costs tend to be very high. Promoting "group" ownership tends to reduce herd 
mobility and is made difficult by the fact that identifying who belongs in the "group" is often quite complex. Different clans or sub-clans may have different degrees of access rights to certain range resources; one sub-clan may have what could be considered primary rights, with others' having secondary claims that are exercised, for instance, in time of drought (Ngaido and McCarthy 2002).

Thus, PES programs and projects must consider the nature and extent of overlapping property rights in these areas, and different contracts can be structured to provide services depending on the underlying property rights. For instance, in certain highly degraded areas where large investments are required or where specific areas of land generate very high environmental services, PES contracts could be structured to pay current rights holders for restrictions or prohibitions on land use under a more traditional state managed arrangement (Ngaido et al. 2002). This strategy is not likely to be cost effective over large land areas that may be demarcated as local tribes managed land or even co-managed by state and local users. Instead, combinations of different tenure systems operating over the relevant spatial scale may enable both an equitable and efficient solution. There is a great deal of interest in many drylands regions to promote innovative property rights systems that enable flexibility in access and use while maintaining or increasing incentives to invest in this vital resources. PES contracts thus need to take into account the value of the current property rights systems in order to develop mechanisms and promote investments that give added-value to the rangelands where possible, and consider options for substituting land use and management practices only in strategically important areas. 


\section{Transaction costs}

Considering the interaction between local communities and potential purchasers, there are three broad classes of transaction costs involved with implementing PES programs: search and negotiation, monitoring, and enforcement costs. As outlined in Scherr et al. (2004), transactions costs can be very high, and often lead to extremely reduced payments actually going to providers in the case of forest-based projects (Niles et al. 2003 cited in Scherr et al. 2004). Below we consider such transactions costs in the context of rangelands.

\section{Search and negotiation costs}

Search and negotiation costs are those arising from identifying a source willing to pay for environmental services and negotiating a contract with that source. Without some centralized clearing-house of information, search costs are likely to be very high, particularly for more isolated, poorer communities where members have limited education and experience dealing with outsiders. Negotiation costs will also be a function of the legal framework under which such contracts are made, plus the extent of bureaucratic procedures that need to be followed in order to secure PES contracts. Networks of local actors are likely to be very important in reducing search and negotiation costs.

\section{Monitoring costs}

Both the agent purchasing the environmental services as well as the local community will face monitoring costs; the distribution of such costs will likely be a negotiating point itself and its level will certainly depend on how difficult it is to verify compliance. Monitoring activities are of two types:

1. Assessing land change in order to verify that appropriate investments or management practices have been made. While increased reforestation/afforestation projects might be easy to verify, costs of verifying that changes in management actions have taken place are 
likely to be very high for most programs. In the USA, government managers of PES schemes are particularly concerned about payments tied to change in management practices and/or change in use of variable inputs, as these are both extremely difficult to monitor. In addition, debates still rage about the causality between different management strategies (e.g. managing grazing pressure) and biomass, particularly in the semi-arid and arid regions (Vetter 2004).

2. Assessing the impact of land use change on the level of provision of ES in order to evaluate the economic benefits for the purchasers. The lack of information to link changes in practices to increased provision of environmental services remains as the "Achilles heel" for most PES programs (Pagiola et al. 2002).

Moreover, both monitoring activities will differ by environmental services provided (Table 3):

- Carbon sequestration: Several advances in measurements of soil carbon pool have been made so that it can be implemented in a cost-effective manner (Lal 2002b). In addition, carbon pool can be monitored at regional scale using remote sensing of the vegetation cover and land use change (given the limits presented above).

- Wind erosion: Assessing the economic impact of dust storms on crop, human and animal health, the economy and environment is very complex and difficult to quantify. According to Squires (2001), it will take several more years to prepare the necessary information to precisely asses the situation.

- Water: Siltation of reservoirs and damage to infrastructure can be used as indicators of changes in run-off and water erosion due to improved rangeland management. However, the extent of this damage is also affected by the highly variable rainfall. Changes in groundwater recharge can be assessed by measuring groundwater levels and water quality with a network of wells or piezometers, although, actual quantification of groundwater recharge is very difficult, because aquifer properties are often highly variable and are rarely isolated units (De Vries and Simmers 2002). Furthermore, process-based simulation models could assist with an evaluation of the effect of land management changes on potential change in the system.

- Biodiversity: The biodiversity of a certain natural environment can be assessed through the regular monitoring of key ecological indicators. These indicators can be flora or fauna species either strictly associated with particularly valuable habitats or playing a key ecological role in the functioning of the whole ecosystem. Monitoring flora and fauna eco-indicators can be carried out by members of local communities or technicians from government institutions or from NGOs, if suitably trained and equipped. 
Table 3--Benefits, costs, and returns of management options for range improvement.

\begin{tabular}{|c|c|c|c|c|}
\hline & Controlled grazing & $\begin{array}{l}\text { Controlled grazing } \\
+ \text { shrub plantation }\end{array}$ & $\begin{array}{l}\text { Controlled grazing } \\
\text { + shrub plantation } \\
\text { + water harvesting }\end{array}$ & $\begin{array}{l}\text { Protected natural } \\
\text { range }\end{array}$ \\
\hline \multicolumn{5}{|l|}{ Environmental benefits } \\
\hline Increased carbon sequestration & $\mathrm{X}$ & $\mathrm{XX}$ & $\mathrm{XX}$ & $\mathrm{XX}$ \\
\hline Plant biodiversity & XXX & $\mathrm{XX}$ & $\mathrm{XX}$ & $\mathrm{XX}$ \\
\hline Animal biodiversity & $\mathrm{XX}$ & $\mathrm{XXX}$ & $\mathrm{XXX}$ & $\mathrm{XX}$ \\
\hline Reduced wind erosion & $\mathrm{XX}$ & $\mathrm{XXX}$ & $\mathrm{XXX}$ & $\mathrm{XX}$ \\
\hline Increased aquifer recharge & $\mathrm{X}$ & $\mathrm{X}$ & $\mathrm{X}$ & $\mathrm{X}$ \\
\hline Flood reduction & $\mathrm{X}$ & $\mathrm{X}$ & $\mathrm{XX}$ & $\mathrm{X}$ \\
\hline Increased water productivity & $\mathrm{X}$ & $\mathrm{XX}$ & XXX & $\mathrm{XX}$ \\
\hline Decreased soil degradation & $\mathrm{X}$ & $\mathrm{X}$ & $\mathrm{X}$ & $\mathrm{X}$ \\
\hline Increase of plant biomass & $\mathrm{XX}$ & $\mathrm{XXX}$ & $\mathrm{XXX}$ & $\mathrm{XXX}$ \\
\hline \multicolumn{5}{|l|}{ Local returns (animal productivity) } \\
\hline First returns (years) & $1-3$ & $2-3$ & $2-3$ & 3-5 \\
\hline Variability of returns & XXX & $\mathrm{X}$ & $\mathrm{X}$ & XXX \\
\hline \multicolumn{5}{|l|}{ Costs } \\
\hline Investment (capital) & $\mathrm{X}$ & $\mathrm{XX}$ & $\mathrm{XXX}$ & $\mathrm{X}$ \\
\hline Monitoring & $\mathrm{XXX}$ & $\mathrm{X}$ & $\mathrm{X}$ & $\mathrm{XX}$ \\
\hline Enforcement & $\mathrm{XXX}$ & $\mathrm{XX}$ & $\mathrm{XX}$ & $\mathrm{XXX}$ \\
\hline Supplementary feeding & - & - & - & $\mathrm{XXX}$ \\
\hline
\end{tabular}

X: Slight benefit/cost; XX: significant benefit/cost; XXX: large benefit/cost; - : reduced cost

\section{Enforcement costs}

Enforcement costs arise in the case of non-compliance and are related to both local, traditional interpretations of property rights as well as the formal legal framework. Those engaging in the contract, and the legal framework under which the contract is signed, must address the very difficult questions of who has both the responsibility and authority for enforcing compliance, what are the punishments for non-compliance, and who has the authority to extract punishments.

Thus, whereas monitoring costs of implementing ES projects might be shared among providers and purchasers, enforcement costs are likely to fall almost entirely on the providers. In other words, groups will have to create legitimate enforcement mechanisms for ensuring compliance amongst group members and bear the full costs of actual enforcement. Costs of enforcement are thus likely to increase as the membership size and spatial distribution of 
members increases, since both are likely to be associated with weaker social links and greater likelihood of multiple, and, perhaps, overlapping authority structures. Similarly, the technical provision of environmental services often requires that those with rights to geographicallydefined resources will need to agree and work together. The ability for different individuals to "self-select" into the group of providers will be far more limited than is the case, for instance, with micro-credit groups. This is true in most cases of management of common resources, but it is worth stressing since other authors have already suggested the success of certain "microcredit" programs as offering a potential solution to structuring PES contracts in regions with communal property rights.

\section{ENVIRONMENTAL SERVICES PROVISION}

In this section we consider issues surrounding supply of environmental services. We consider several management approaches that have been implemented to address land degradation in the rangelands of CWANA, since many of these programs that aim to halt land degradation contain activities necessary to generate the PES identified above. Then, we look at the individual and collective incentives to provide environmental services under several management scenarios. Given that various forms of communal property rights continue to prevail at the local level and based on the nature of externalities involved in the provision, monitoring, and enforcement of environmental public goods, we expect that collective action will play a crucial role in organizing communities to manage the transaction costs associated with the implementation of PES. We conclude the section with a discussion on the implication of heterogeneity in individual incentives for the design of institutions to enable local people to provide environmental services. 


\section{Technical options}

Until now, the principal intervention in the region has been the government-led establishment of shrub plantations and rangeland reserves. Extensive areas have been planted to fodder shrubs as Atriplex spp. (Gintzburger et al. 2000). After periods of resting, native vegetation between the shrubs becomes re-established and produces nearly as much annual biomass as the shrubs; the shrubs also serve as a stockpile of both fuel wood and forage, where forage is used during drought and dry seasons when no other green grazing is available.

Such government-led interventions have had limited success in controlling access to and use of such rangelands, simply because costs of demarcating and guarding the reserves have been relatively high. Without effective grazing management, the plantations revert to degraded rangeland. Such restoration is therefore ineffective without a change in the land use and management that caused the degradation in the first place.

To minimize high management, monitoring, and enforcement issues, several shrubplantation projects have been implemented where specific social groups, such as extended families or pastoral cooperatives, play a key role. Groups are compensated during the shrubgrowing period (2-3 years) based on the opportunity cost of grazing foregone, and thereafter the identified group members are guaranteed exclusive use of the areas. Though such approaches appear to be much more successful, often a legal framework that would enable wide-scale adoption of such approaches is lacking. However, such an approach is quite consistent with other PES programs being implemented for different services around the world; that is, acknowledgement of the foregone opportunities during initial stages is explicitly recognized and assurance of receiving benefits in the future is a key aspect of program development and the institutional framework. 
Beside range rehabilitation programs, the use of water-harvesting structures, such as small earth or stone dikes, to capture rainfall run-off is a complementary approach to improving rangelands and to reduce floods. Construction of check dams, recharge ponds or wells, or diversions in wadis will slow down the runoff water and will generally improve the recharge of water to the aquifer (Yahyaoui et al. 2002).

The development of a PES program could induce the development of global management plans for community rangelands, with the appropriate mix of technologies and other management options such as rotational grazing that would guarantee the sustainability of the system. This is discussed in the next section.

\section{Individual incentives and collective provision}

Below, we consider individual incentives to invest and/or change management of the natural resource base and the group's ability to work together to provide these locally generated environmental services from local common pool resources

Individual incentives to undertake any rehabilitation/management of the rangelands will depend on the technical options chosen. A better economic analysis of the technologies presented above is therefore crucial in order to answer the following questions: Does the PES scheme require substantial investment (shrub plantations vs. native rangeland grazing management)? If so, are the benefits produced pure public goods, in the sense that all benefits accrue to everyone with access rights, e.g. shade bushes planted on common grazing lands? Or, are there mixed "private-public" benefits, e.g. flocks from individuals who planted shrubs can graze the shrubs? How long will it take for returns to be generated? Where the PES program is fully implemented, will such benefits from investment be easily verified, or will fluctuating climatic conditions make it difficult to assess the benefits in the short- to medium 
term? Similarly, are individuals' actions easily monitored, or do fluctuating climate conditions or a large spatial scale make it difficult to ascertain the extent to which outcomes are related to human activities? What is the scale and scope of the project, and, thus, how many people and/or institutions will need to coordinate, monitor, and enforce the PES program?

Taking as a starting point the vast literature on managing common pool resources (Ostrom 1990; Baland and Platteau 1996), we assume that individual incentives are likely to favour collective action where the returns to ES investments or changes in management practices yield greater returns when more people participate, where such investments produce both public and private goods, where monitoring individuals' contributions is relatively easy, where returns to the investment begin to accrue immediately, and where such returns are less variable.

The actual costs and benefits to different investments and management options are likely to be context specific. Nonetheless, we propose a subjective classification of environmental benefits, implementation costs and returns characteristics for some management options based on the inter-disciplinary experience of the authors in countries of the WANA region (Table 3). For example, investing in shrubs on the common rangeland is easy to verify locally and perhaps even by purchasers; it provides a pure global public good in terms of carbon sequestration and a common good in terms of forage produce for animals. The group required for such investments may be quite small, but the investment may require large up-front outlays, and benefits do not accrue until some time in the future. Reducing grazing pressure through controlled grazing is likely to generate pure local and public goods in terms of increased bio-diversity, reduced soil erosion, and increased biomass. On the other hand, benefits to herders in terms of animal productivity depend on everyone else' abiding by 
the new limits; both monitoring and enforcement costs are likely to be very high in order to ensure compliance. The spatial scale of enforcement, plus accounting for all those who have periodic access to the rangeland, is likely to increase these costs still further (McCarthy 2004). Impacts on future animal productivity are likewise uncertain and variable. Nevertheless, these results are illustrative, and a proper economic evaluation will have to be implemented on a case basis.

A last point that will have to be taken into account while planning PES scheme is how heterogeneity amongst users is likely to affect individuals' incentives to comply with PES programs. Greater heterogeneity of users is likely to increase the costs of collective action for implementing any PES program. Users might differ in terms of what rangeland products they rely on (forage, fuelwood, medicinal herbs), in terms of exploitation levels (herd sizes), the degree of access, use, management, and exclusion rights (primary vs. secondary or tertiary rights holders), in terms of total wealth (those with and without access to outside income), in terms of social or cultural backgrounds, etc. Benefits to various PES programs are likely to differ across these different types of users, meaning that negotiating amongst users is likely to be quite high. Determining a schedule of who should receive benefits and how much may be quite contentious, though groups may agree that all PES payments be put toward investment in provision of other local public goods (wells, schools, health clinics, roads), functioning like local administrative revenue. Determining the distribution of costs where investments are concerned is also likely to be more difficult in more heterogeneous groups. In the end, however, the resulting distribution of costs and benefits to individuals will affect their likelihood of actively supporting various PES programs, and thus the costs of monitoring and enforcement that the group as a whole will have to bear. 


\section{CONCLUSION}

Renewed attention is being given to rangelands and the people dependent on them; governments in the CWANA region in particular have shown increased political will to tackle the difficult issues of poverty and degradation of the rangelands. Nonetheless, because of the social, legal, and economic dimensions associated with non-private ownership of rangelands, purely technical options to combat desertification and maintain rangeland productivity are more limited than the options available for development in more favourable areas, meaning that identifying and evaluating alternative management and institutional options is crucial.

Here we have considered both the types of gains that can be expected from improved management of rangelands, as well as some of the institutional issues that need to be addressed if the people living in these environments are to take advantage of PES programs. There are indeed potentially very large benefits to be gained from well-managed rangelands in the dry areas to both rangeland users as well as society at large, particularly wind erosion reduction, conservation of biodiversity, soil carbon sequestration, and improved water productivity. Actually, if the per hectare contribution of rangelands to the global services is smaller that from forests, the contribution applies to vast expanses so that the total services are substantial.

Other than the important task of quantifying and improving scientific knowledge of these various benefits, institutional issues remain. One of the major concerns regarding contracts between providers and purchasers in these environments is the underlying property rights structure which influences just who the service providers are. To make sure that the poor and marginalized groups do not lose their pre-existing rights (be it partial, secondary, or fuzzy), effective mechanisms for identifying current rights holders need to be put into place, 
perhaps with community members and government officials, and/or local NGO's or civic groups.

Once the group is established, questions regarding the investment and payment schedule, and the monitoring and enforcement mechanisms must be addressed. The transaction costs of implementing such a program will be shaped not only by the individual's incentives, but also by the institutional design and the cooperative capacity of the group to make and enforce collective decisions. Therefore, local community members are far better placed to undertake monitoring and enforcement and to provide at least the first-line of conflict resolution mechanisms. To ensure legitimacy and fairness, such conflict resolution mechanisms should allow for appeal to non-local mediators and to the formal judicial system. Finally, heterogeneity in interests has to be dealt with directly and should be built into the distribution of costs and benefits. 


\section{REFERENCES}

Aidoud A., and D.Nedjraoui. 1992. The steppes of alfa ( Stipa tenacissima L) and their utilization by sheep. In Plant animal interactions in Mediterranean-type ecosystems .MEDECOS VI, Gréce.

Alix, J., A. de Janvry, E. Sadoulet and J.M. Torres. 2005. An Assessment of Mexico's Payments for Environmental Services Program. FAO report.

Allen-Diaz, B. et al. 1996. Rangelands in a changing climate: Impacts, adaptations and mitigation. Scientific-Technical Analyses. Contribution of Working group II to the Second Assessment Report of the Intergovernmental Panel on Climate Change. Cambridge University Press, pp. 131-158.

Baland, J.M., and J.P. Platteau. 1996. Halting Degradation of Natural Resources: Is there a Role for Rural Communities? Food and Agricultural Organization of the United Nations, Oxford Clarendon Press.

Bienabe, E. and R.H. Hearne. 2005. Public preferences for biodiversity conservation and scenic beauty within a framework of environmental services payments. Forest Policy and Economics (in press).

BirdLife International 2004. [Online] www.birdlife.org/action/science/species/index.html

Boulanouar, B., A. Chriyaa and A.Boutouba. 2000. Moroccan experience with fodder shrub research and development. In: Fodder Shrub Development in Arid and Semi-Arid Zones by Gintzburger, G., M. Bounejmate, and A. Nefzaoui.

Bouwer, H. 2002. Artificial recharge of groundwater: hydrogeology and engineering. Hydrogeology Journal 10: 121-142.

Costanza, R., R. D’Arge, R. De Groot, S. Farber, M. Grasso, B. Hannon, S. Nafem, K. Limburg, J. Paruelo, R.V. O’Neill, R. Raskin, P. Sutton, M. Van den Belt. 1997. The value of the world's ecosystem services and natural capital. Nature 387, 253-260.

CSIRO. 2000. Public health impact of wind erosion, Media release, ref2000/179. [Online] http://www.csiro.au/index.asp?id=dust\&type=mediaRelease

De Vries, J.J. and I. Simmers. 2002. Groundwater recharge: an overview of processes and challenges. Hydrogeology Journal, 10:5-17.

FAO, IAEA, UNDESA, UNESCO. 2003. Groundwater management - The search for practical approaches. Water Reports 25. FAO, Rome, Italy.

Farage, P., J. Pretty, and A. Ball. 2003. Biophysical Aspects of Carbon Sequestration in Drylands. University of Essex, UK. 
Farber, S.C, R. Costanza, M.A. Wilson. 2002. Economic and ecological concepts for valuing ecosystem services. Ecological Economics 41:375-392.

Fisher MJ, Rao IM, Ayarza MA, Lascano CE, Sanz JI, Thomas RJ and Vera RR. 1994. Carbon storage by introduced deep-rooted grasses in the South American savannas. Nature 371, 236237.

Forage and grazing terminology committee. 1992. Terminology for grazing lands and grazing animals. J. Prod. Agric. 5(1): 191-201.

Gintzburger, G., M. Bounejmate, and A. Nefzaoui. 2000. Fodder Shrub Development in Arid and Semi-Arid Zones. Proceeding of the workshop on Native and Exotic Fodder Shrubs in Arid and Semi-arid Zones, 27 Oct - 2 Nov 1996, Hammamet Tunisia. ICARDA, Aleppo, Syria.

Goodhue, R. and N. McCarthy. 1999. Fuzzy Access: Modeling Grazing Rights in SubSaharan Africa. In: McCarty, N, B. Swallow, M. Kirk, and P. Hazell (ed). Property Rights, Risk and Livestock Development in Africa. ILRI, IFPRI.

IUCN 2003. The world conservation union's red list of threatened species: www.redlist.org

Kosoy, N., M. Martinez-Tuna, R. Muradian, and J. Martinez-Alier. 2006. Payments for environmental services in watersheds: Insights from a comparative study of three cases in Central America. Ecological Economics (in press).

Lal, R. 2002a. Carbon sequestration in dryland ecosystems of West Asia and North Africa. Land Degrad. \& Dev. 13: 45-59.

Lal, R. 2002b. Soil carbon dynamics in cropland and rangelands. Env. Pollution 116:353-362.

Landell-Mills, N. and I. T. Porras. 2002. Silver bullet or fools' gold? A global review of markets for forest environmental services and their impact on the poor. IIED.

Levy, G.J., I. Shainberg, and J. Morin. 1986. Factors affecting the stability of soil crusts in subsequent storms. Soil Sci. Soc. Am. J. 50: 196-201.

Lemberg, B., J.W. Mjelde, J.R. Conner, R.C. Griffin, W.D. Rosenthal, J.W. Stuth. 2002. An interdisciplinary approach to valuing water from brush control. Journal of the American Water resources Association 38(2): 409-422.

Mayrand, K. and M. Paquin. 2004. Payments for environmental services: a survey and assessment of current schemes. Report for the Commission for Environmental Cooperation of North America. Unisféra International Centre. Montreal.

McCarthy, N. 2004. Managing Resources in Erratic Environments. An Analysis of Pastoralist Systems in Ethiopia, Niger, and Burkina Faso. Research Report 135. International Food Policy research Institute. Washington, DC.

Middleton N. and D. Thomas. 1997. World atlas of desertification - second edition. UNEP. 
Ngaido, T. and N. McCarthy 2002. Managing Externalities and Improving Pastoral Production and Livelihood Strategies. Proceedings of the Regional Workshop on Land Issues in Africa, Kampala, Uganda, April 29-May 2, 2002. Washington, DC: The World Bank.

Ngaido, T., N. McCarthy, and M. Di Gregorio. 2002. International conference on policy and institutional options for the management of rangelands in dry areas. Workshop Summary paper. CAPRI WP No. 23.

Niamir-Fuller, M. 1999. Managing mobility in African rangelands. The legitimization of transhumance. London: Intermediate Technology Publications.

Northcutt G. 2001. Some downward costs of upwind erosion. Erosion control. Sept/Oct 2001.

Ostrom, E. 1990. Governing the Commons: The Evolution of Institutions for Collective Action. New York: Cambridge University Press.

Quezada,V. 2003. Economic valuation of environmental goods and services of high Andean grasslands in Peru: policies for sustainable management. Paper presented at the Regional Forum on payment schemes for environmental services in watersheds. FAO, 9-12 June 200\3, Arequipa, Peru.

Pagiola, S., and I.M. Ruthenberg. 2002. Selling Biodiversity in a Coffee Cup: Shade-grown Coffee and Conservation in Mesoamerica. In: S. Pagiola, J. Bishop, and N. Landell-Mills (eds.), Selling Forest Environmental Services: Market-based Mechanisms for Conservation and Development. London: Earthscan.

Pagiola, S., Agostini, P., Gobbi, J., de Haan, C., Ibrahim, M., Murgueitio, E., Ramirez, E., Rosales, M., Ruiz, J.P. 2004. Paying for biodiversity conservation services in agricultural landscape. Environment Department Papers, vol. 96. World Bank.

Pagiola, S., A. Arcenas and G. Platais. 2005. Can Payments for Environmental Services Help Reduce Poverty? An Exploration of the Issues and the Evidence to Date from Latin America. World Development, 33 (2): 237-253

Piper, S. 1989. Measuring the particulate pollution damage from wind erosion in the Western United States. Journal of Soil and Water Conservation, 44: 70-75.

Rae, J. 2003. Getting in steppe: the evolution of participatory institutions for rangeland management in the Syrian Arab Republic". In: Land reform 2000-2002: Land settlement and cooperatives. FAO.

Reynolds, R., J. Belnap, M. Reheis, P. Lamothe and F. Luiszer. 2001. Aelion dust in Colorado plateau soils: Nutrient inputs and recent change in source. PNAS, 98(13) : 7123-7127.

Robert, M. 2001. Soil carbon sequestration for improved land management. FAO, W. Soil Res. Rep. No 96.

Saydam A. C. and H.Z. Senyuva. 2002. Deserts: Can they be the potential suppliers of bioavailable iron? Geophysical research letters, 29(11): 19. 
Scherr, S., A. White, and A. Khare, with contributions from M. Inbar and A. Molar. 2004. For services rendered: The current status and future potential of markets for the ecosystem services provided by tropical forests. ITTO Technical Series No. 21. Yokohama, Japan: International Tropical Timber Organziation.

Serra G., M. Abdallah, A. Abdallah, G. Al Qaim, T. Fayed, A. Assaed, and D. Williamson. 2003. Discovery of a relict breeding colony of Northern Bald Ibis Geronticus eremita in Syria: still in time to save the eastern population ? Oryx, 38 (1): 1-7.

Serra G., M. Abdallah, A. Assaed, G. Al Qaim, A. Abdallah. 2005. A long-term bird survey of central Syrian desert (2000-2003). Sandgrouse, 27(1): 9-23.

Shinn, E.A., G.W. Smith, J.M. Prospero, P. Betzer, M.L. Hayes, V. Garrison and R.T. Barber. 2000. African dust and the demise of Caribbean coral reefs. Geophysical Research Letters. 27(19): 3029-3032.

Sierra, R., and E. Russman. 2006. On the efficiciency of environmental service payments: A forest conservation assessment in the Osa Peninsula, Costa Rica. Ecological Economics 59: 131141.

Sivakumar, M.K.V., M.A. Zöbisch, S. Koala and T. Maukonen. 1998. Wind Erosion in Africa and West Asia: Problems and Control Strategies. ICARDA, Aleppo, Syria.

Smith, P., Martino, D., Cai, Z., Gwary, D., Janzen, H.H., Kumar, P., McCarl, B., Ogle, S., O’Mara, F., Rice, C., Scholes, R.J., Sirotenko, O., Howden, M., McAllister, T., Pan, G., Romanenkov, V., Schneider, U., Towprayoon, S., Wattenbach, M. \& Smith, J.U. 2006. Greenhouse gas mitigation in agriculture. Philosophical Transactions of the Royal Society, B. (in press).

Squires, V.R. 2001. Distinguishing natural causes and human intervention as factors in accelerated wind erosion: the development of environmental indicators. In: UNCCD (eds.) Global Alarm Dust and Sandstorms from the World's Drylands.

Taiyab, N. 2005. The market for voluntary carbon offsets: a new tool for sustainable development? Gatekeeper series 121. IIED.

Turner, R.K., J. Paavola, P. Cooper, S. Farber, V. Jessamy and S. Georgiou. 2003. Valuing nature: lessons learned and future research direction. Ecological Economics. 46:493-510.

UNCCD. 2001. Global alarm dust and sandstorms from the World's Drylands.

Vetter, S. 2004. Rangelands at equilibrium and non-equilibrium: Recent developments in the debate around rangeland ecology and management. Cape Town: Programme for Land and Agrarian Studies, University of the Western Cape, South Africa.

West, N.E.. 1993. Biodiversity of rangelands. Journal of Range Management 46 (1): 2-13.

Winkler, R. 2006. Valuation of ecosystem goods and services. Part 1: An integrated dynamic approach. Ecological Economics. 59: 82-93. 
Wylie, B.K., T.G. Gilmanov, D.A. Johnson, N.A. Saliendra, K. Akshalov, L.L. Tieszen, B.C. Reed, and E. Laca. 2004. Intra-seasonal mapping of CO2 flux in rangelands of Northern Kazakhstan at One-kilometer resolution. Environmental Management 33 1: S482-S491.

Yahyaoui, H., Chaieb, H., Ouessar, M. 2002. Impact des travaux de conservation des eaux et des sols sur la recharge de la nappe de Zeuss-Koutine. In JWater harvesting in Mediterranean zones: an impact assessment and economic evaluation, De Graaf and M. Ouessar (eds.). Tropical Resource Management Papers 40, Wageningen, The Netherlands. 


\section{List of CAPRi Working Papers}

01 Property Rights, Collective Action and Technologies for Natural Resource Management: A Conceptual Framework, by Anna Knox, Ruth Meinzen-Dick, and Peter Hazell, October 1998.

02 Assessing the Relationships between Property Rights and Technology Adoption in Smallholder Agriculture: A Review of Issues and Empirical Methods, by Frank Place and Brent Swallow, April 2000.

03 Impact of Land Tenure and Socioeconomic Factors on Mountain Terrace Maintenance in Yemen, by A. Aw-Hassan, M. Alsanabani and A. Bamatraf, July 2000 .

04 Land Tenurial Systems and the Adoption of a Mucuna Planted Fallow in the Derived Savannas of West Africa, by Victor M. Manyong and Victorin A. Houndékon, July 2000 .

05 Collective Action in Space: Assessing How Collective Action Varies Across an African Landscape, by Brent M. Swallow, Justine Wangila, Woudyalew Mulatu, Onyango Okello, and Nancy McCarthy, July 2000.

06 Land Tenure and the Adoption of Agricultural Technology in Haiti, by Glenn R. Smucker, T. Anderson White, and Michael Bannister, October 2000.

07 Collective Action in Ant Control, by Helle Munk Ravnborg, Ana Milena de la Cruz, María Del Pilar Guerrero, and Olaf Westermann, October 2000.

08 CAPRi Technical Workshop on Watershed Management Institutions: A Summary Paper, by Anna Knox and Subodh Gupta, October 2000.

09 The Role of Tenure in the Management of Trees at the Community Level: Theoretical and Empirical Analyses from Uganda and Malawi, by Frank Place and Keijiro Otsuka November 2000.

10 Collective Action and the Intensification of Cattle-Feeding Techniques a Village Case Study in Kenya's Coast Province, by Kimberly Swallow, November 2000.

11 Collective Action, Property Rights, and Devolution of Natural Resource Management: Exchange of Knowledge and Implications for Policy, by Anna Knox and Ruth Meinzen-Dick, January 2001. 
12 Land Dispute Resolution in Mozambique: Evidence and Institutions of Agroforestry Technology Adoption, by John Unruh, January 2001.

13 Between Market Failure, Policy Failure, and "Community Failure": Property Rights, Crop-Livestock Conflicts and the Adoption of Sustainable Land Use Practices in the Dry Area of Sri Lanka, by Regina Birner and Hasantha Gunaweera, March 2001.

14 Land Inheritance and Schooling in Matrilineal Societies: Evidence from Sumatra, by Agnes Quisumbing and Keijuro Otsuka, May 2001.

15 Tribes, State, and Technology Adoption in Arid Land Management, Syria, by Rae, J, Arab, G., Nordblom, T., Jani, K., and Gintzburger, G., June 2001.

16 The Effects of Scales, Flows, and Filters on Property Rights and Collective Action in Watershed Management, by Brent M. Swallow, Dennis P. Garrity, and Meine van Noordwijk, July 2001.

17 Evaluating Watershed Management Projects, by John Kerr and Kimberly Chung, August 2001.

18 Rethinking Rehabilitation: Socio-Ecology of Tanks and Water Harvesting in Rajasthan, North-West India, by Tushaar Shah and K.V.Raju, September 2001.

19 User Participation in Watershed Management and Research, by Nancy Johnson, Helle Munk Ravnborg, Olaf Westermann, and Kirsten Probst, September 2001.

20 Collective Action for Water Harvesting Irrigation in the Lerman-Chapala Basin, Mexico, by Christopher A. Scott and Paul Silva-Ochoa, October 2001.

21 Land Redistribution, Tenure Insecurity, and Intensity of Production: A Study of Farm Households in Southern Ethiopia, by Stein Holden and Hailu Yohannes, October 2001.

22 Legal Pluralism and Dynamic Property Rights, by Ruth Meinzen-Dick and Rajendra Pradhan, January 2002.

23 International Conference on Policy and Institutional Options for the Management of Rangelands in Dry Areas, by Tidiane Ngaido, Nancy McCarthy, and Monica Di Gregorio, January 2002.

24 Climatic Variablity and Cooperation in Rangeland Management: A Case Study From Niger, by Nancy McCarthy and Jean-Paul Vanderlinden, September 2002. 
25 Assessing the Factors Underlying the Differences in Group Performance:

Methodological Issues and Empirical Findings from the Highlands of Central Kenya, by Frank Place, Gatarwa Kariuki, Justine Wangila, Patti Kristjanson, Adolf Makauki, and Jessica Ndubi, November 2002.

26 The Importance of Social Capital in Colombian Rural Agro-Enterprises, by Nancy Johnson, Ruth Suarez, and Mark Lundy, November 2002.

27 Cooperation, Collective Action and Natural Resources Management in Burkina Faso: A Methodological Note, by Nancy McCarthy, Céline Dutilly-Diané, and Boureima Drabo, December 2002.

28 Understanding, Measuring and Utilizing Social Capital: Clarifying Concepts and Presenting a Field Application from India, by Anirudh Krishna, January 2003.

29 In Pursuit Of Comparable Concepts and Data, about Collective Action, by Amy Poteete And Elinor Ostrom, March 2003.

30 Methods of Consensus Building for Community Based Fisheries Management in Bangladesh and the Mekong Delta, by Parvin Sultana and Paul Thompson, May 2003.

31 Formal and Informal Systems in Support of Farmer Management of Agrobiodiversity: Some Policy Challenges to Consolidate Lessons Learned, by Marie Byström, March 2004.

32 What Do People Bring Into the Game: Experiments in the Field About Cooperation in the Commons, by Juan-Camilo Cárdenas and Elinor Ostrom, June 2004.

33 Methods for Studying Collective Action in Rural Development, by Ruth MeinzenDick, Monica Di Gregorio, and Nancy McCarthy, July 2004.

34 The Relationship between Collective Action and Intensification of Livestock Production: The Case of Northeastern Burkina Faso, by Nancy McCarthy, August 2004.

35 The Transformation of Property Rights in Kenya's Maasailand: Triggers and Motivations by Esther Mwangi, January 2005.

36 Farmers' Rights and Protection of Traditional Agricultural Knowledge, by Stephen B. Brush, January 2005. 
37 Between Conservationism, Eco-Populism and Developmentalism - Discourses in Biodiversity Policy in Thailand and Indonesia, by Heidi Wittmer and Regina Birner, January 2005.

38 Collective Action for the Conservation of On-Farm Genetic Diversity in a Center of Crop Diversity: An Assessment of the Role of Traditional Farmers' Networks, by Lone B. Badstue, Mauricio R. Bellon, Julien Berthaud, Alejandro Ramírez, Dagoberto Flores, Xóchitl Juárez, and Fabiola Ramírez, May 2005.

39 Institutional Innovations Towards Gender Equity in Agrobiodiversity Management: Collective Action in Kerala, South India, by Martina Aruna Padmanabhan, June 2005.

40 The Voracious Appetites of Public versus Private Property: A View of Intellectual Property and Biodiversity from Legal Pluralism, by Melanie G. Wiber, July 2005.

41 Who Knows, Who Cares? Determinants of Enactment, Awareness and Compliance with Community Natural Resource Management Bylaws in Uganda, by Ephraim Nkonya, John Pender, Edward Kato, Samuel Mugarura, and James Muwonge, August 2005.

42 Localizing Demand and Supply of Environmental Services: Interactions with Property Rights, Collective Action and the Welfare of the Poor, by Brent Swallow, Ruth Meinzen-Dick, and Meine von Noordjwik, September 2005.

43 Initiatives for Rural Development through Collective Action: The Case of Household Participation in Group Activities in the Highlands of Central Kenya, By Gatarwa Kariuki and Frank Place, September 2005.

44 Are There Customary Rights to Plants? An Inquiry among the Baganda (Uganda), with Special Attention to Gender, by Patricia L. Howard and Gorettie Nabanoga, October 2005.

45 On Protecting Farmers' New Varieties: New Approaches to Rights on Collective Innovations in Plant Genetic Resources by Rene Salazar, Niels P. Louwaars, and Bert Visser, January 2006.

46 Subdividing the Commons: The Politics of Property Rights Transformation in Kenya’s Maasailand, by Esther Mwangi, January 2006.

47 Biting the Bullet: How to Secure Access to Drylands Resources for Multiple Users, by Esther Mwangi and Stephan Dohrn, January 2006. 
48 Property Rights and the Management of Animal Genetic Resources, by Simon Anderson and Roberta Centonze, February 2006.

49 From the Conservation of Genetic Diversity to the Promotion of Quality Foodstuff: Can the French Model of 'Appellation d'Origine Contrôlée' be Exported? by Valérie Boisvert, April 2006.

50 Facilitating Collective Action and Enhancing Local Knowledge: A Herbal Medicine Case Study in Talaandig Communities, Philippines, by Herlina Hartanto and Cecil Valmores, April 2006.

51 Water, Women and Local Social Organization in the Western Kenya Highlands, by Elizabeth Were, Brent Swallow, and Jessica Roy, July 2006.

52 The Many Meanings of Collective Action: Lessons on Enhancing Gender Inclusion and Equity in Watershed Management, by Laura German, Hailemichael Taye, Sarah Charamila, Tesema Tolera, and Joseph Tanui, July 2006.

53 Decentralization and Environmental Conservation: Gender Effects from Participation in Joint Forest Management, by Arun Agrawal, Gautam Yadama, Raul Andrade, and Ajoy Bhattacharya, July 2006.

54 Improving the Effectiveness of Collective Action: Sharing Experiences from Community Forestry in Nepal, by Krishna P. Achyara and Popular Gentle, July 2006.

55 Groups, Networks, and Social Capital in the Philippine Communities, by Marie Godquin and Agnes R. Quisumbing, October 2006.

56 Collective Action in Plant Genetic Resources Management: Gendered Rules of Reputation, Trust and Reciprocity in Kerala, India, by Martina Aruna Padmanabhan, October 2006.

57 Gender and Local Floodplain Management Institutions--A case study from Bangladesh, by Parvin Sultana and Paul Thompson, October 2006.

58 Gender Differences in Mobilization for Collective Action: Case Studies of Villages in Northern Nigeria, by Saratu Abdulwahid, October 2006.

59 Gender, Social Capital and Information Exchange in Rural Uganda, by Enid Katungi, Svetlana Edmeades, and Melinda Smale, October 2006. 
60 Rural Institutions and Producer Organizations in Imperfect Markets: Experiences from Producer Marketing Groups in Semi-Arid Eastern Kenya, by Bekele Shiferaw, Gideon Obare and Geoffrey Muricho, November 2006.

61 Women's Collective Action and Sustainable Water Management: Case of SEWA's Water Campaign in Gujarat, India, by Smita Mishra Panda, October 2006. 